\title{
RELIVANSI ETIKA-POLITIK MENURUT ARIESTOTELES BAGI PRAKTEK POLITIK UANG MENJELANG PEMILU DI INDONESIA
}

\author{
Oleh: \\ Elisa Maria Paskalia (162881) \\ STKIP Widya Yuwana
}

\section{Pendahuluan}

Politik berasal dari bahas Yunani (politika- yang behubungan dnegan negara) dengan akar katanya (polites - warga negara) dan (polis - Negara kota). Politik berasal dari bahasa Yunani yaitu polis yang berarti kota atau negara kota. Kata ini berpengaruh ke wilayah Romawi seingga bagsa Romawi memiliki istilah ars politica yang berarti kemahiran tentang masalah-masalah kenegaraan. Politik pun di kenal dalam bahasa Arab dengan kata siyasah yang berarti mengurus kepentingan seseorang. Pengarang kamus al Muhith mengatakan bahwa sustu ar-ra'iyata siyasatan berarti saya memerintahnya dan melarangnya. Dalam artian lebih luas politik adalah proses pembentukan dan pembagian kekuasaan dalam masyarakat yang antara lain berwujud proses pembuatan keputusan, khususnya dalam Negara. Pengertian ini merupakan upaya penggabungan antara berbagai definisi yang berbeda mengenai hakikat politik yang dikenal dalam ilmu politik.

Ilmu politik mempelajari alokasi dan trasper kekuasaan dalam pembuatan keputusan, peran dan sistem pemerintahan termasuk pemerintah dan organisasi internasional, perilaku politik dan kebijakan publik. Mereka mengukur keberhasilan pemerintahan dan kebijakan khusus dengan memeriksa beberapa faktor, termasuk stabilitas keadilan, kesejahteraan material, dan kedamaian. Didalam ilmu politik terdapat juga teori politik, teori politik merupakan kajian mengenai konsep penentuan kajian politik bagaimana mencapai tujuan tersebut dengan segala konsekuensinya. Bahasan dalam teori politik antara lain adalah filsafat politik, konsep tentang sistem politik, negara, masyarakat, kedaulatan, legitimasi, lembaga negara, perubahan sosial, pembangunan politik, perbandingan politik, dsb.

Antara ilmu politik dan filsafat politik ada perbedaan, filsafat politik berbicara tentang segala sesuatu yang berhubungan dengan politik. Berbeda dengan ilmu politik yang langsung berbicara tentang masalah-masalah politik dari segi ke ilmuan atau keilmiahan atau strategi pencapaian sasaran politik. Jadi, yang mmebedakan antara filsafat politik dan ilmu politik ialah objek fomalnya, atau dimesi filusuf pembahasannya. Filsafat politik juga tidak sama dengan pemikiran politik pada umumnya. Pemikiran politik berkaitan langsung dengan 
kehidupan politik yang lantas terarah pada penegasan-penegasan strategi untuk mengejar tujuan politis tertentu. Namun demikian filsafat politik bagaimanapun lahir dari kehidupan politik yang konkrit.

Aristoteles merekonstruksi politik sebagai lapangan ilmu yang melingkupi segala disiplin ilmu yang lain. Politik mencakup etika, sejarah, ilmu budaya, ekonomi, ilmu-ilmu eksta dan teknologi, manajemen dan seterusnya. Cakupan yang sangat luas ini menandakan bahwa politik adalah ilmu yang mengatasi segala ilmu lain. Kontruksi ilmu Aristotelian ini memiliki konsekuensi besar bahwa manusia-manusia yang terlibat dalam kancah ilmu demikian adalah mereka yang capable. Artinya, politikus dalam makna Aristotelian mengandaikan kapasitas kemampuan yang mengatasi kecakapan teknik sehari-hari. Politikus harus mengerti etika, ilmu sosial, kebijakan publik, nilai-nilai budaya, filsafat bangsa, dan sejenisnya.

Dewasa ini politik disalah gunakan oleh para elit politk untuk kepetingan pribadi maupun golongan tertentu. Hingga banyak sekali pangangan yang mengatakan bahwa politik itu kotor. Hitler mengatakan tidak ada lapangan kehidupan yang demikia kotor seperti politik. Pembenaran terhadap prinsip "politik itu kotor" berasal dari paham pemikiran yang memisahkan antara moral dan politik. Moral merupakan lapangan pertimbangan dosa dan tidak dosa. Sedangkan politik adalah lapangan kekuasaan melulu. Dalam mengajar dan membela kekuasaan, pertimbangan dosa atau tidak dosa disisihkan, karena bukan saja akan menganggu, tekat untuk memutuskan tindakan tertentu, melainkan juga terutama tidak relevan.

Di Indonesia sendiri politik dilepaskan dari etika sehingga politik di Indonesia bukan lagi sebuah ilmu yang agung, melainkan lapangan kehidupan yang kotor. Salah satu praktek politik yang membuat politik itu menjadi kotor ialah praktek politik uang pada saat mengjelang pemilu, para elit memberikan uang kepada masyarakat untuk memilih paslon atau partai tertentu. Praktek politik uang ini sudah menjadi hal yang lumrah dalam dinamika politik di Indonesia, poltik uang yang terjadi hampir disetiap sudut daerah-daerah di Indonesia. Politik uang berlangsung dalam setiap tingkatan pemilihan di Indonesia, baik di tingkat pusat sampai tingakt terandah yaitu desa. Praktek politik uang yang terjadi di Indonesia ini diakarenakan para pelaku politik memisahkan antara etika dan politik. Maka dari itu untuk mengatasi permasalahan politik uang yang sudah merajalele di Indonesia ini, para pelaku politik harus melihat hubungan etika-politik menurut Aristoteles. 


\section{Pembahasan dan Analisis}

\section{Praktek Politik Uang}

Money Politic dalam bahasa Indonesia adalah suap, artinya suap dalam kamus Bahasa Indonesia adalah uang sogok. Politik uang adalah pertukaran uang dengan maksud untuk menentukan posisi seseorang, kebijakan yang akan dikeluarkan dan keputusan politik yang engatasnamakan kepentingan rakyat namun sesungguhnya hanya untuk kepentingan pribadi, kelompok maupun partai politik. Politik uang adalah upaya mempengaruhi orang lain atau masyarakat dengan mengiming-imingi materi atau dapat juga diartikan jual-bei suara pada proses politik dan kekuasaan serta tindakan membagi-bagi uang, baik milik pribadi atau partai untuk mempengaruhi suara pemilih. Ada juga yang mengartikan politik uang sebagai tindakan jual beli suara pada proses politik dan kekuasaan. Tindakan itu bisa terjadi dalam jangkauan yang luas, dari tingkat paling kecil yaitu pemerintahan kepala desa hingga pemilihan umum.

Praktek politik uang di Indonesia sudah sungguh menjadi tradisi di ajang pemilihan umum di Indonesia. Praktek politik uang sudah ada semenjak masa orde baru, karena dalam masa orde baru preside diangkat oleh MPRS/DPRD yang terdiri dari beberapa anggota. Selain itu dalam pemerintahan aerah pada masa orde baru juga tidak dipilih secara langsung seperti sekarang ini namun kepala daerah diangkat oleh presiden, yang mekanisme pemilihannya di DPRD juga di control oleh presiden sehingga dalam praktek tersebut memiliki peluang besar agar presiden dapat melakukan money politics kepada DPRD agar pemimpin disetiap daerah sepemahaman dengan pemerintahan pusat.

Seperti yang tercantum pada undang-undang Nomor 5 Tahun 1974 tentang pokok-pokok Pemerintah di Daerah, yang mengatakan bahwa kepala daerah diangkat oleh Presiden. Namun pada masa era reformasi kemudian dibentuk peraturan perundang-undangan baru Undang-undang Nomor 6 Tahun 2004 yang mengatur tentang pemilihan umum kepala daerah secara langsung. Namun dalam faktanya dimasa reformasi ini masih banyak praktik-praktik politik uang yang dilakukan oleh para paslon-paslon dalam pemilu baik di tingkat daerah maupu pemerintahan umum ditingkat pusat.

Biasanya politik uang dikaitkan dengan maslaah suap-menyuap dengan saran memenangkan salah satu kandidat dalam pemilu. Padahal apabla dilihat secara lebih luas, politik uang dapat juga dihubungkan dengan segala macam pelanggaran 
menyangkut dana di dalam konteks politik (termasuk masalah kepartaian dan pemilu). Kita mengetahui yang paling menonjol adalah kecurangan dengan penyuapan. Namun, ada pula bentuk-bentuk lain yang juga melanggar norma hukum yang perlu diwaspadai, khususnya mendapatkan dana dari sumber terlarang serta tidak melaporkan dana tersebut (Santosos, 2007:63).

Ada bermacam-macam bentuk politik uang yang terjadi saat menjelang pemilu, adapun bentuk-bentuk itu ialah: Pertama, berbentuk uang: uang merupakan salah satu modal politik seseorang dalam mencapai sesuatu kekuasaan dan uang merupakan salah satu alat yang digunakan untuk menghasilkan kekuasaan politik dengan cara melakukan praktik politik uang untuk medapatkan suara. Kedua, bentuk fasiltas umum: dalam masa-masa pemilihan umum untuk mendapatkan suara, tak jarang para pasangan calon memberikan dana kepada masyarakat untuk membangun fasilitas-fasilitas umum yang sedang dilakukan oleh masyarakat dengan cara memberikan semen, pasir, dan sebagainya. Dengan tujuan masyarakat memilih paslon tersebut karena paslon telah mau mmeberikan bantuan dalam menyelesaikan pembangunan fasilitas umum bagi masyarakat.

Para paslon dan partai politik juga melakukan berbagaimacam strategi untuk menarik hati masyarakat dengan menggunakan politik uang. Adapun strategi yang dilakuakn itu: Pertama, serangan fajar: serangan pajar adalah istilah yang digunakan untuk menyebut bentuk politik uang dalam rangka membeli suara satu calon yang akan menduduki suatu posisi sebagi pimpinan politik pada pagi hari sebelum pemilu dilakukan. Kedua, mobilisasi masa: mobilisasi massa adalah memberikan uang atau manfaat lainnya kepada pemilih dengan tujuan untuk mendukung suatu kandidat/partai tertentu. Pemberian uang dimaksudkan sebagai imbalan atau insentif untuk memanipulasi hasil pemilu. Sehingga dalam pemilihan umum itu kandidat tersebut dapat memperoleh suara masyarakat benyak dengan memobilasi masyarakat.

\section{Hubungan Etika-Politik Menurut Aristoteles}

Pembahasan tentang hubungan etika dan politik ini sangatlah penting karena langsung menyentuh kodrat (natura) hidup bersama dari manusia. Hubungan etika dan politik adalah pembahasan yang sepintas jelas tetapi menjadi kompleks diamana menyimak realitas peradapan kehidupan manusia. untuk mendalami pembahasan tentang hubungan etika dan politik ini kita akan melihat pandangan Aristoteles tentang hubungan etika dan politik. 
Menurut Aristoteles, etika dan politik sangat berhubungan satu dengan yang lain. Hal ini bisa dilihat dari cara bagimana Aristoteles mengembangankan teori politiknya (politics) dengan berangkat dari prinsip etikanya (Nicomacthen Ethics). Jadi, bagi Aristoteles politik dan etika bukan hanya berhubungan satu dengan yang lain, melainkan terutama politik mengandaikan etika, dan etika mengalami pencetusan kesempurnaanya. Etika Aristoteles adalah etika kebaikan, yang artinya dia mengariskan bahwa setiap aktivitas memiliki tujuan mengejar kebaikan. Jadi apapun aktivitas itu haruslah mengejar kebaikan. Titik tolak Aristoteles yang mengedepankan telos (tujuan) ini dapat dipandang sebagai cikal bakal teleogidme etika.

Hubungan antara etika dan politik Aristoteles dapat dilihat dalam Nicomachean Ethics, segala sesuatu yang berhubungan dengan aktivitas selalu menuju kepada sesuatu kebaikan tertentu (etika). Begitu juga dalam Politics, persekutuan aktivitas hidup bersama apa pun juga lahir dan dibangun dengan tujuan menggapai pada tujuan kebaikan tertentu pula. Karena polis merupakan persekutuan puncak kesempurnaan hidup bersama, maka tujuannya pastilah untuk kebaikan paling tinggi. Dengan demiian, politik adalah sistem tata hidup bersama dalam polis tunduk pada dan mengandaikan etika kebaikan sekaligus merupakan puncak kesempurnaan cetusan etika. Maka dari itu menurut Aristoteles etika dan politik saling berhubungan. Hubungnnya dalam realitas bahwa etika adalah pendasaran dari politik. Atau, politik menemukan dasar kodratinya pada etika.

Tindakan etis Aristoteles adalah actus humanus (korespondensi dengan kodrat akal budi). Aristotels merekomendasikan politik sebagai lapangan ilmu yang melingkupi segala disiplin ilmu yang lain. maka dari itu politik harus mencakup etika, sejarah, ilmu budaya, ekonomi, ilmu-ilmu eksakta dan teknologi manajemen dan seterusnya. Dalam Aristoteles hubungan etika dan politik itu ada jembatan yang saling berhubungan dan berkaitan, jadi tidak ada jurang yang menjadi pemisah antara etika dan politik, karena keduanya saling berhubungan.

\section{Relivansi Etika dan Politik Menurut Aristoteles bagi Politik Uang di Indonesia}

Hari-hari ini dinamisme politik di negara kita mengalami emerosotan makna. Politik yang bemakna mendalam sebagai "tata kelola hidup bersama" terasa tidak ada artinyanya lagi oleh dominasi perkara-perkara jabatan dan atau rekayasa yang tidak bemutu. Salah satunya praktek politik uang yang terjadi di Indonesia, pada saat pemilihan umum. Setiap pemilihan umum para paslon dan partai tertentu berusaha 
menarik hati rakyat dengan memberikan uang dimana tujuan dari politik uang ini agar paslon tertentu bisa menduduki jabatan yang ingin didapatkannya itu.

Meskipun praktek politik uang ini sebenarnya salah satu tindakan pidana yang di rumuska Pasal 73 ayat (3) Undang-undang tentang PEMILU tahun 1999. Meskipun begitu namun para pelaku politik tetap saja melakuakn praktek politik uang pada saat pemilu. Para elit politik melakukan berbagai cara supaya bisa mendapatkan kedudukan di dalam pemerintahan. Mereka yang menjadi kandidat dalam berbagai jenjang pemilu bukan karena kapasistas dan kapabilitasnya sebagai politis yang mengakar dan mamahami atau mempersentasikan aspirasi rakyat.

Melihat praktek politik uang yang masih terus terjadi disetiap pemilihan umum di Indonesia, maka dari itu politik Indonesia hendaknya menanamkan hubungan etika dan politik menurut Aristoteles agar para pelaku politik tidak membedakan politik dan etika. Aristoteles mengatakan bahwa manusia itu adalah mahluk yang berbeda dalam polis (kodrat manusia itu ada dalam polis). Karena manusia itu hendak menggapai apa yang baik dan polis itu terdiri dari berbagai manusia, maka konsekuensinya: polis itu juga pasti terarah pada kebaikan. Dari pendapat Aristoteles ini tampak bahwa Aristoteles tidak melepaskan politik dari etika. Politik adalah sistem hidup bersama dalam polis yang hendak merengguh kebaikan.

Jika diamati politik di Indonesia ini sudah kehilangan maknanya sebagai "tata kelola hidup bersama." Praktek politik di Indonesia saat ini mengacu kepada gaya berpikir Machiavell, yang berpendapat bahwa etika dan politik itu tidak bisa disatukan ada jurang yang dalam diantara keduanya. Tidak ada ruang bagi pengejaran kebaikan disana. Yang ada para pelaku politik bersaing dengan melakukan berbagai cara untuk mengejar kekuasaan. Manusia Indonesia rupanya tidak menyadari kakekat mereka sebagai mahluk yang ada bersama dengan manusia lain. Sehingga setiap orang saling bersaing dan berusaha mengalahkan satu dengan yang lainnya.

Dalam situasi saat ini haruslah meluhat gagasan Aristoteles, sebgai insfirasi bagi perkembangan politik Indonesia agar menjadi lebih baik. Dimana negara haruslah menyadari fungsinya sebagai pengemban amanat bersama untuk mewujudkan kebaikan bersama. Secara konkrit hal ini tentu dilaksanakan oleh para pemegang kekuasaan, pejabat, angota MPR/DPR, dan para pelaku politik. Kebaikan bersama menjadi syarat mutlak dalam setiap aktivitas politik. Kebaikan yang hendak diraih bukanlah kebaikan pribadi maupun golongan, maka kepentingan umum wajib 
di utamakan. Konsekuensinya: segala hal harus ditujukan kepada pemenuhan kepentingan bersama.

Untuk mengatasi politik uang yang selalu terjadi disetiap pemilu perlu adanya penyadaran diri seperti yang di gagasakan oleh Aristoteles.bahwa kebaikan perlu dikedepankan oelh setiap individu. Setiap warga hendaknya menyadari bahwa tujuan terdalam dari kehadirannya sebagai manusia adalah pencapaian kebaikan. Maka jika setiap orang menginsyafi bahwa masing-masing terarah kepada apa yang baik, maka masyarakat yang terbentukpun akan terwarnai olehnya. Jika dilihat gagasan ini haruslah menjadi pegangan yang terus diingat oleh para pelaku politik sehingga ketika mereka ingin melakukan sesuatu yang bertentangan dengan etika, mereka bisa menyadari bahwa kehadiran mereka itu member kesejahteraan bai rakyat, bukan malah memberikan rakyat kesejahteraan dengan politik uang yang jelas-jelas melanggar etika dan merendahkan martabat orang yang mererima uang suap itu.

Gagasan-gagasan yang di buat oleh Aristoteles haruslah menjadi dasar bagi politik di Indonesia. Agar setiap pribadi Indonesia ini menyadari bahwa segala sesuatu harus diarahkan kepada keaikan begitu juga halnya dengan politik, politik harulah diarahkan kepada kebaikan. Dengan manusia Indonesia menyadari bahwa dirinya adalah pribadi yang mendatangkan kebaikan tentu praktek politik uang yang merupaka tindakan pelanggaran moral ini akan teratasi. Gagasan Aristoteles tentang hubungan politik dan etika ini sangat memberikan sumbangan yang besar bagi kehidupan politik Indonesia dewasa ini terutama untuk mangatasi politik uang yang terus terjadi didalam pemilu. Maka dari itu sudah saatnya manusia-manusia Indonesia membuka mata dan merenungkan gagasan Aristoteles ini, karena gagasan yang disumbangkan Aristoteles untuk kehidupan politik ini sangat relevan bagi kebersamaan hidup bersama. Untuk itu supaya bangsa ini tidak terus terjerumus dalam politik uang yang sudah merajalela setiap pemilu harus dibangun kehidupan politik yang beretika. 


\section{Kesimpulan}

Jika melihat realita politik di Indonesia saat ini telah banyak mengkonsumsi dari pemikiran Mechiavellian. Diamna politik dipisahkan dari etika, Mechiavellian berpendapat bahwa etika dan politik itu tidak bisa disatukan karena ada jurang pemisah diantara keduanya. Pemikiran Machiavellian ini sangat terlihat jelas dalam realita politik di Indonesia saat ini. Dimana para pemegang kekuasaan melepaskan politik dari etika, sehingga banyak sekal kekacauan yang terjadi di Indonesia dikarenakan oleh para elit politik. Para elitit poltitik melakuak segala cara untuk mendapatkan kekuasaan sehingga politik di Indonesia ini menjadi sangat kotor. Salah satu contoh dari kotornya politik di Indonesia yaitu terjadinya praktek politik uang yang terjadi disetiap pemilu di Indonesia. Dimana para penguasa melakukan segala cara agar mendapatkan posisi di pemerintahan, hal ini menunjukn bahwa politik di Indonesia telah dipisahkan dari etika.

Manusia Indonesia sudah melupakan hakekatnya sebagai mahluk yang ada bersama manusia lain. Dalam situasi politik di Indonesia yang begitu kacau saat ini sudah waktunya masyarakat Indonesia merenungkan gagasan Aristoteles bahwa politik itu tidak bisa dipisahkan dari etika. Karena etika dan politik sangat berhubungan satu dengan yang lain. Politik dan etika bukan hanya berhubungan satu dengan yang lain, melainkan terutama politik itu mengandaikan etika, dan etika mengalami pencetusan kesmepurnaanya.

Maka dari itu sudah saatnya gagasan Aristoteles tentang hubungan etika dan politik menjadi dasar kehidupan politik di Indonesia, agar kehidupan bersama di Indonesia kembali memmeluk kebaikan sebgai hal yang harus dikejar. Dimana setiap individu atau setiap warga negara menyadari bahwa tujuan terdalam dari kehadirannya sebgaia manusia adalah pencapaian kebaikan. Keterarahan politik pada etika ini mengandung banyak implasi, dan salah satu diantaranya adalah pendepanan kebaikan. Dengan begitu tidak adalagi yang namanya politik uang terjadi pada setiap pemilu di Indonesia. Untuk itu politik Indonesia harus mulai bangkit dari segala kekacauan politik yang terjadi terutama praktek politik uang yang diamna para penguasa telah memisahkan politik dengan etika demi mendapatkan kekuasan. Untuk mengatasi kekacauan politik, politik Indonesia harus mulai membangun kehidupan politik yang beretika. 


\section{Daftar Pustaka}

Dewantara. A.W. 2017 Diskursus Filsafat Pancasila Dewasa ini. Yogyakarta: Kanisius

Riyanto.E. Armada. 2011 Berfilsafat Politik. Yogyakarta: Kanisius

Pendidikan Kewarganegaraan

http://eprints.umm.ac.id/35920/3/jiptummpp-gdl-yudikurnia-48898-3-babii.pdf

https://id.wikipedia.org/wiki/Politik

https://journal.unnes.ac.id/sju/index.php/snh/article/download/27028/11996/

Dewantara, A. (2017). Diskursus Filsafat Pancasila Dewasa Ini.

DEWANTARA, A. W. (2016). GOTONG-ROYONG MENURUT SOEKARNO DALAM PERSPEKTIF AKSIOLOGI MAX SCHELER, DAN SUMBANGANNYA BAGI NASIONALISME INDONESIA (Doctoral dissertation, Universitas Gadjah Mada). 